ZOOLOGIA 27 (3): 403-407, June, 2010

doi: $10.1590 /$ S1984-46702010000300012

\title{
Rediscovery of Melanepyris (Hymenoptera: Bethylidae): a new synonym of Epyris
}

\author{
Celso O. Azevedo ${ }^{1,3} \&$ Isabel D. C. C. Alencar ${ }^{2}$ \\ ${ }^{1}$ Departamento de Biologia, Universidade Federal do Espírito Santo. Avenida Marechal Campos 1468, 29040-090 Vitória, \\ Espirito Santo, Brazil. E-mail: bethylidae@gmail.com \\ 2 Instituto Federal de Educação, Ciência e Tecnologia do Espírito Santo, Campus Santa Teresa. Rodovia ES-080, km 21, \\ 29660-000 Santa Teresa, Espírito Santo, Brazil. E-mail: idccalencar@gmail.com \\ ${ }^{3}$ Corresponding author.
}

\begin{abstract}
Melanepyris Kieffer, 1913 was proposed to accommodate a single species of Epyris Westwood, 1832, E. imicola Kieffer, 1913, mainly based on the absence of the posterior propodeal carina. Today, Melanepyris includes only two nominal species. The type-material of these species has been considered lost since their original description. In this study, the single known adult male (holotype) of Melanepyris asiaticus Kieffer, 1922 from the Philippines has been rediscovered, redescribed and illustrated. Melanepyris asiaticus is transferred to Epyris Westwood due to the following features: scutellar groove absent, well separated scutellar pits and lower mesopleural fovea large and with undefined upper margin. We checked the original description of M. imicola and concluded that it also fits the definition of Epyris perfectly, except for the (described) absence of a posterior carina. However, the thickness of the posterior carina of the propodeal disc varies within species of different Epyrinae genera. The diagnostic characters used by Kieffer to create Melanepyris and other genera from Epyris are briefly discussed. Melanepyris is proposed as a new junior synonym of Epyris, with the transfer of M. imicola to Epyris.
\end{abstract}

KEY WORDS. Chrysidoidea; Epyrini; Ethiopic Region; new combination; Oriental Region.

KiEfFER (1913a) created Melanepyris to accommodate the African species Epyris imicola Kieffer, 1913 which has glabrous eyes, propodeal disc without posterior carina, and simple claws. Latter, Kieffer (1922) described a Philippinean species, Melanepyris asiaticus Kieffer, 1922, with simple claws and propodeal disc with inconspicuous posterior carina. In his original description, KIEFFER (1913a) did not state whether M. asiaticus has glabrous or hairy eyes.

Both species are known only from their types, which have not been studied since the time of their original descriptions (KiefFer 1913b, 1922) and had been considered lost. In a recent visit to the Muséum National d'Histoire Naturelle in Paris, we were able to find the type of M. asiaticus. During analysis of the latter, we have concluded that Melanepyris is a junior synonym of Epyris Westwood.

Given the scenario described above, the present study has the following goals: (1) to propose Melanepyris as a new junior synonym of Epyris, with the transfer of its two nominal species to Epyris, and (2) to redescribe M. asiaticus.

\section{MATERIAL AND METHODS}

The holotype of $M$. asiaticus was borrowed from the Muséum National d'Histoire Naturelle, Paris (MNHN).

Measurements and indices used in this study are as follows: body length - from the apex of clypeus to the posterior margin of the last metasomal segment, excluding the male genitalia or the female sting; (LH) length of head in frontal view from the vertex crest to the median apical margin of clypeus; (WH) width of head in frontal view - maximum width including eyes; (WF) width of frons in frontal view - minimum width, usually at a virtual line that crosses the anterior margin of compound eyes; (HE) height of eye in lateral view - across its maximum height (length); (OOL) ocellar-ocular line in laterodorsal view - the shortest distance from posterior margin of compound eye to posterior ocellus; (WOT) width of ocellar triangle in frontal view - maximum width, including ocelli; (DAO) diameter of anterior ocellus in frontal view; (VOL) vertex-ocular line in dorsal view, distance from eye top to vertex crest.

The nomenclature of the integument sculpture follows Harris (1979), and general terms follow Evans (1964) and AzEvEDo (1999).

\section{TAXONOMY}

\section{Epyris Westwood, 1832}

Epyris Westwood, 1832: 129. Type-species: Epyris niger Westwood, by monotypy.

Melanepyris Kieffer, 1913a: 108. Type-species: Melanepyris imicola Kieffer, by monotypy. Syn. nov. 


\section{Epyris asiaticus (Kieffer, 1922) comb. nov.}

Figs 1-7

Melanepyris asiaticus Kieffer, 1922: 84-85, male (description); Kurian, 1954: 277 (catalog); Kelner-Pillault, 1959: 411 (taxonomy); Baltazar, 1966: 200 (catalog); Gordh \& Móczár, 1990: 133 (catalog).

Holotype. Male: [PhiLIPpines], Mindanao [Island], Dapitan, [8 $\left.8^{\circ} 40^{\prime} \mathrm{N} 123^{\circ} 25^{\prime} \mathrm{E}\right]$, Baker [leg.] (MNHN) (examined).

Diagnosis. Male. Length $4.88 \mathrm{~mm}$. Black. Mandible with five teeth. Clypeus with median lobe angulate. Antenna very long. Eye hairy, with sparse and long pilosity. Frons coriaceouspunctate. Vertex almost straight. Temple parallel. Pronotal disc carinate anteriorly. Scutellar pit large, sub-oval. Propodeal disc with median carina nearly complete; discal carina on anterior half of disc; posterior carina inconspicuous;_posterior corner foveolate. Mesopleuron with upper margin of lower fovea open. Fore wing with metacarpus. Genitalia: paramere elongate; cuspis elongate, deeply divided into two arms; aedeagus short.

Description. Male. Length $4.88 \mathrm{~mm}$; LFW $3.7 \mathrm{~mm}$. Color. Head and mesosoma black, except dark castaneous anterior margin of pronotal disc; metasoma dark castaneous, nearly black; clypeus black; mandible castaneous with margins darker; antenna and palpi castaneous; legs castaneous, except dark castaneous coxae; tegula castaneous; wings hyaline, veins castaneous. Head (Fig. 1). Mandible with five apical teeth, upper four teeth rounded and very small, lowermost large and sharp, length $0.6 \mathrm{x}$ apical mandibular width; base of mandible excavate (Fig. 2). Clypeus coriaceous-punctulate, base not covered medially by frons; median lobe angulate, median carina complete, sharp, straight in profile; lateral lobe short, much narrower than median lobe. Antenna $3.39 \mathrm{~mm}$, last segment reaching metasomal segment II; first four antennal segments in ratio of 20:11:15:18; flagellomeres thick, segment III 1.6x longer than thick; flagellar pubescence dense, subappressed and short, with few erect setae. Antennal scrobe projected forward, partially overhanging clypeus, carinate dorsally. Toruli distant one from each other about 2.0x their diameter. Malar space very small, eye reaching upper mandibular condyle. Eye with sparse, long hairs. Frons shinning, coriaceous-punctate, punctures small, shallow and sparse. WH 0.86x LH; WF 0.61x WH; WF 1.18x HE; OOL 1.89x WOT; frontal angle of ocellar triangle acute; distance from posterior ocellus to vertex crest $1.22 \mathrm{x}$ DAO. Vertex almost straight. VOL 0.9x HE. Temple profile parallel in dorsal view with round corner. Occipital carina well outlined throughout its extension, visible in dorsal view. Palpi long, maxillary palpus surpassing occipital carina ventrally. Mesosoma (Figs 3-4). Thoracic dorsum shinning, mostly weakly coriaceous and punctate as frons, except anterior third of mesoscutum apunctuated. Pronotal disc flat; anterior margin convex and carinate, carina high and sharp; posterior margin not paralleled by series of foveae (Fig. 4). Notaulus conspicuous, reaching anterior margin of mesoscutum in resting posi- tion, not reaching posterior margin of mesoscutum, parallel but slightly arched medially, progressively wide posterad. Parapsidal furrows visible only on posterior half of mesoscutum, not reaching its posterior margin, conspicuous, parallel, straight, and comparatively wide. Scutellar pits large, oblong, sub-oval, slightly inclined backwards laterally, distant from each other 0.42x their length, space between them slightly depressed but not grooved. Metanotum visible between scutellum and propodeal disc, foveolate medially. Propodeal disc as wide as long; anterior carina wide, median carina delicate, narrowing posterad, anterior half straight, posterior half somewhat irregular, nearly reaching posterior carina; discal carina straight, parallel, slightly shorter than anterior half of disc; lateral carina conspicuous and sharp, paralleled by longitudinal depression microcarinate transversally; space between discal carinae rugulose; posterior area colliculate, space between discal and lateral carinae aciculate-strigulate; posterior carina inconspicuous; ;posterior corner foveolate, fovea small and shallow (Fig. 4). Lateral of propodeum aciculate and areolate below, lower carina conspicuous and sharp. Propodeal declivity coriaceous, with median and lateral microstrigate carinae. Mesopleuron coriaceous above to coriaceous-punctate below, punctures shallow and large; subtegular fovea irregularly elliptical with posterior slender groove; anterior fovea undefined; lower fovea with lower margin ill-defined and upper margin completely open; central pit subtriangular (Fig. 3). Wings. Fore wing with metacarpus $0.84 \mathrm{x}$ as long as basal vein; stigma slender; transverse median vein arched. Hind wing with one basal hamulus and two apical ones. Legs. Fore femur $2.38 \mathrm{x}$ as long as wide. Tibiae and tarsi not spinose. Mid and hind tibiae and hind tarsus with long setae standing out regular pubescence. Claws simple. Metasoma. Tergites I-IV polished and without dorsal setae, otherwise weakly coriaceous with dorsal setae; tergites progressively with more lateral setae posterad; sternites weakly coriaceous with few setae, except for the more setose hypopygium. Hypopygium with posterior margin straight. Genitalia (Figs 5-7): paramere elongate, about 2.0x longer than basiparamere, apical margin convex, membranous expansion apical-ventral and with irregular contour; cuspis elongate, slightly shorter than paramere, deeply divided into two arms, ventral arm slightly longer than dorsal arm; digitus with apical margin denticulate, its apex not reaching cuspis apex; aedeagus bottle-shaped, short, its apex aligned with basal half of paramere, apex emarginate medially; apodeme not extending beyond genital ring, base straight and not dilated.

\section{Epyris imicola Kieffer, 1913 comb. rev.}

Epyris imicola Kieffer, 1913b: 5-6, male (description). Melanepyris imicola Kieffer, 1913a: 108 (transfer to Melanepyris); Kieffer, 1914: 418 (taxonomy); Gordh \& Móczár, 1990: 133 (catalog).

Holotype. Male: Kenya, Tiwi, [ $\left.4^{\circ} 14^{\prime} \mathrm{S} 39^{\circ} 34^{\prime} \mathrm{E}\right], 2 . \mathrm{XI} .1911$ (not examined). 

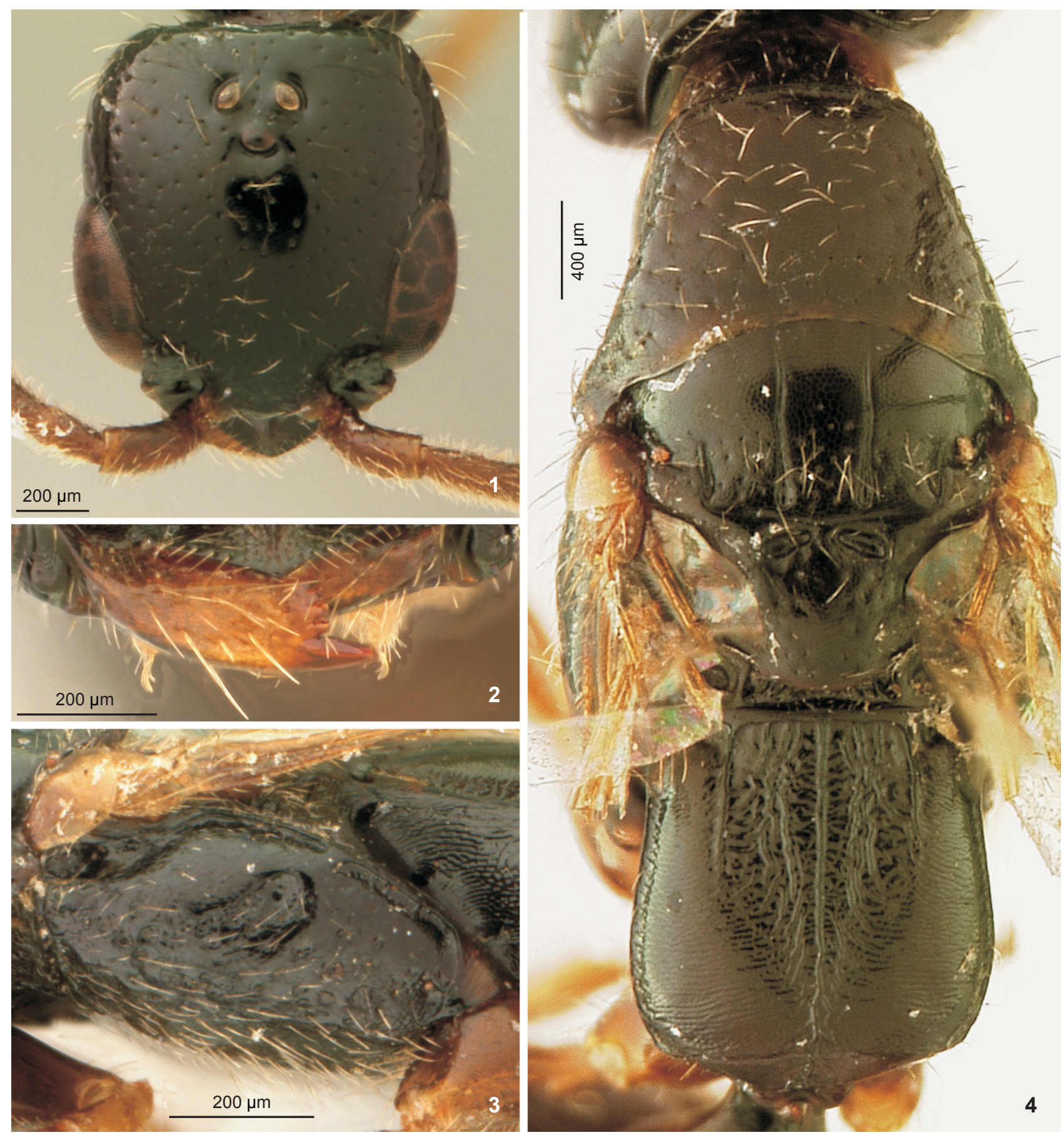

Figures 1-4. Epyris asiaticus comb. nov., holotype, male: (1) head, dorsal view; (2) mandible, frontal view; (3) mesopleuron, lateral view; (4) mesosoma, dorsal view.

Diagnosis. Male. Length $2.0 \mathrm{~mm}$. Black. Head elongate, temple parallel. Eye glabrous. Scutellum pits round. Propodeal disc slightly longer than wide, median carina complete, discal carina absent on posterior half, lateral carina present, posterior carina absent. Fore wing with stigma elongate, metacarpus absent. 

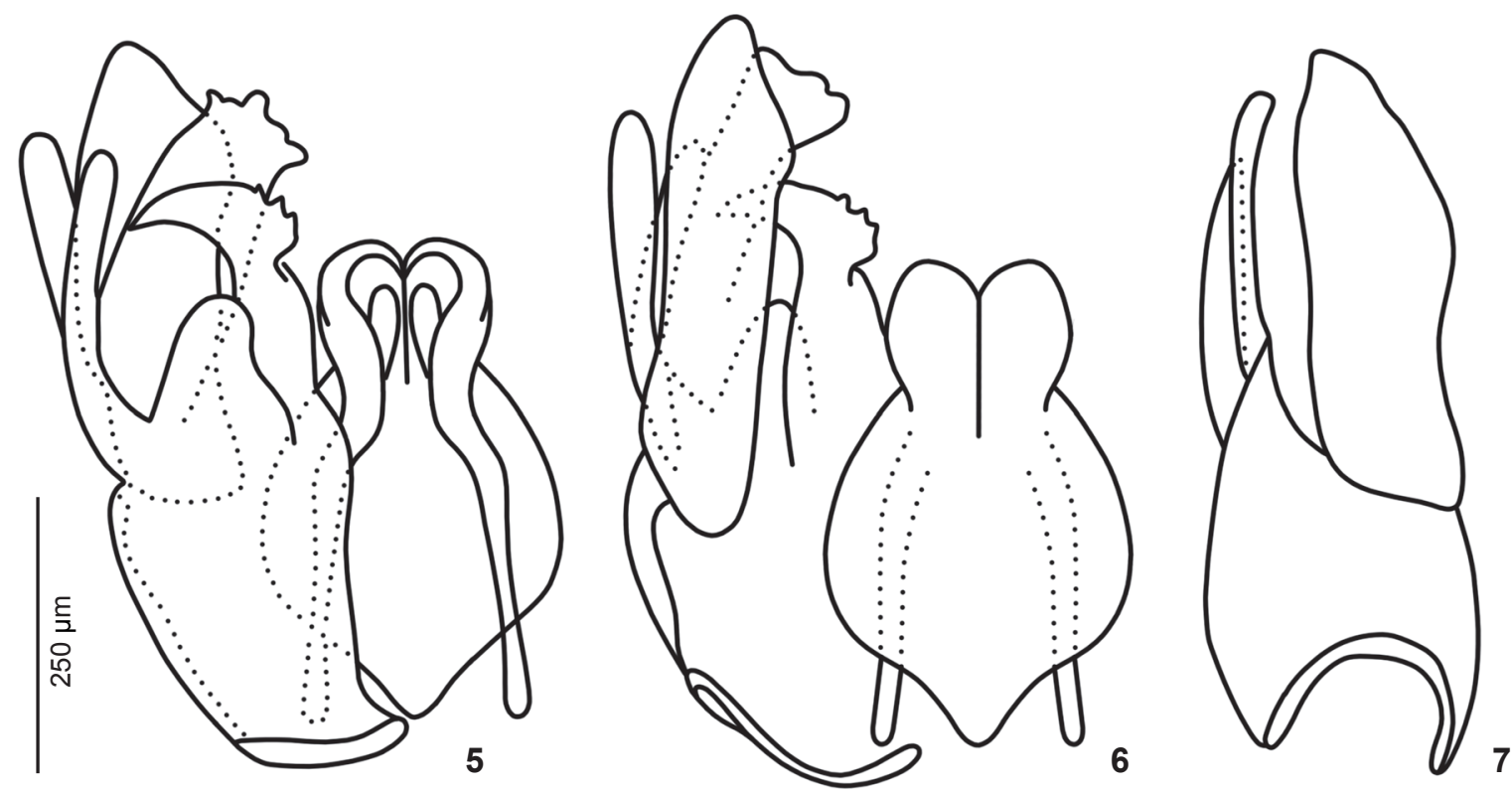

Figures 5-7. Epyris asiaticus comb. nov., genitalia of holotype, male: (5) dorsal view; (6) ventral view; (7) lateral view.

Description. Male. Length $2.0 \mathrm{~mm}$. Black, smooth and brilliant, basal antennal segments and legs dark castaneous. Head elongate, temple parallel. Eye glabrous, HE 0.33x VOL, close to mandible. Antenna with 13 segments, pubescent, segments II and III slightly longer than thick, others $2.0 \mathrm{x}$ as long as thick. Thorax narrower than head. Pronotum elongate, $1.5 \mathrm{x}$ as long as mesonotum. Parapsidal furrow parallel. Scutellum pits round. Propodeal disc slightly longer than wide, coriaceous, median carina complete, discal carina absent on posterior half, lateral carina present, posterior carina absent. Fore wing with basal vein more inclined than transverse vein, but not more elongate, radial vein $0.75 \mathrm{x}$ as long as basal vein, not reaching margin, stigma elongate, metacarpus absent, submedian cell slightly wider than median cell. Legs brown, trochanter simple, slightly longer than thick, fore tarsus with segment I as long as segments II-IV together, which are slightly longer than thick, segment V longer than segments III-IV together, claw simple.

Remarks. The holotype is considered lost. It was supposed to be deposited either at the MNHN or at the Musée Royal de l'Afrique Centrale (MRAC) in Tervuren, because the types from three of the five species described by KIEFFer (1913b) had been deposited at the former institution, and one at the latter. We have visited both museums but have not been able to find it. Thus, the description below corresponds to an adaptation of the original one.

\section{DISCUSSION}

KiefFer (1913a, b) stated that the propodeal disc of Epyris imicola lacks the posterior carina. Since the holotype, and only specimen known for this species has been lost, we cannot con- firm this condition. However, even though KIEFFER (1922) described the propodeal disc of $M$. asiaticus lacking a posterior carina , a careful examination of the holotype indicates that this feature is present, though inconspicuous. Thus, it is also possible that E. imicola bears an inconspicuous posterior carina on the propodeal disc.

KIEFFer (1913a) established eight genera from several species identified as belonging to Epyris at that time. From these genera, Parepyris, Psilepyris, and Artiepyris were synonymized with Epyris; Lyssepyris and Xantepyris were synonymized with Pseudisobrachium; Chlorepyris was synonymized with Rhabdepyris; Misepyris was synonymized with Holepyris; and Lytepyris was synonymized with Disepyris. Therefore, only Melanepyris remained as a valid genus. However, Chlorepyris had its generic status recently reinstated by WAICHERT \& AzEVEDO (2009).

The main characters used by Kiefrer (1914) to key out Melanepyris from the related genera such as Xantepyris, Dipristocera Kieffer, 1914 and Lyssepyris were exactly the same ones used to separate the genus from Epyris. However, the eye pilosity, the thickness of the posterior carina of the propodeal disc, and the number of teeth on the claws are very variable within species of Epyris and in many other genera of Epyrinae. The eyes can be either glabrous or hairy; the posterior carina of the propodeal disc varies from absent to very thick and complete; and the claw can be simple, bifid or even trifid. Thus, these conditions are meaningless to establish a genus in Epyrinae. The few previous cladistic analyzes of Bethylidae emphasize this argument (see Lanes \& Azevedo 2008, Polaszer \& Krombein 1994, Terayama 1995, 1996, 2003, 2006). 


\section{ACKNOWLEDGEMENTS}

We thank Eliane De Coninck and Claire Villemant for their kind reception during the visits to MRAC and MNHN, respectively; to CNPq (grants \#500280/00-8, \#303216/2004-2 and \#306331/2007-7) for providing financial support and a fellowship to the first author; to Programa de Taxonomia of CNPq grant \#563953/05-5 for providing financial support; to CAPES for providing a fellowship to the second author. The trip to Paris of the second author was partially supported by The Ernest Mayr (year grant 2008) and FAPES grant \#41807812/ 2008.

\section{LITERATURE CITED}

Azevedo, C.O. 1999. Revision of the Neotropical Dissomphalus Ashmead, 1893 (Hymenoptera, Bethylidae) with median tergal processes. Arquivos de Zoologia 35: 301-394.

BaLtAZAR, C.R. 1966. A catalog of Philippine Hymenoptera (with a Bibliography, 1758-1963). Pacific Insects Monograph 8: 1-488.

Evans, H.E. 1964. A synopsis of the American Bethylidae (Hymenoptera, Aculeata). Bulletin of the Museum of Comparative Zoology 132: 1-222.

GordH, G. \& L. Móczár. 1990. A catalog of the world Bethylidae (Hymenoptera). Memoirs of the American Entomological Institute 46: 1-364.

HARRIS, R.A. 1979. A glossary of surface sculpturing. Occasional Papers in Entomology 28: 1-31.

Kelner-Pillault, S. 1959. Les Bethylidae et les Belytinae (Insectes Hyménoptères) provenant de la collection de l'abbe J. J. Kieffer. Muséum National d'Histoire Naturelle, Serie 2, 31: 41-422.

KIEFFer, J.J. 1913a. Démembrement du genere Epyris. Bollettino di Laboratorio di Zoologia Generale e Agraria della R. Scuola Superiore d'Agricoltura in Portici 7: 108.

KiefFer, J.J. 1913b. Insectes Hyménoptères I, Proctotrupidae, Cynipidae et Evaniidae. Voyage de Ch. Alluaud et R. Jeannel en Afrique Orientale (1911-1912). Paris, Librairie Albert Schulz, 41p.

KiefFer, J.J. 1914. Bethylidae. Das Tierreich 41: 1-595.

Kieffer, J.J. 1922. Philipine Serphidae (Proctotrupidae). The Philippine Journal of Science 20: 65-103.

Kunian, C. 1954. Catalogue of the Oriental Bethyloidea. Agra University Journal of Research Science 3: 25-288.

Lanes, G.O. \& C.O. Azevedo. 2008. Phylogeny and Taxonomy of Sclerodermini (Hymenoptera, Bethylidae, Epyrinae). Insect Systematics \& Evolution 39: 55-86.

Polaszer, A. \& K.V. Krombein. 1994. The genera of Bethylinae (Hymenoptera, Bethylidae). Journal of Hymenoptera Research 3: 9-105.

Terayama, M. 1995. The phylogeny of the Bethylidae wasps tribe Sclerodermini (Hymenoptera, Bethylidae). Proceedings of the Japanese Society of Systematic Entomology 54: 6-73.

Terayama, M. 1996. The phylogeny of the Bethylid wasp subfamily Pristocerinae (Hymenoptera, Bethylidae). Japanese Journal of Entomology 64: 58-601.

Terayama, M. 2003. Phylogenetic Systematics of the family Bethylidae (Insecta: Hymenoptera) Part II. Keys to subfamilies, tribes and genera in the world. Academic Reports of the Faculty of Engineering of the Tokyo Polytechnic University 26: 1-29.

Terayama, M. 2006. The Insects of Japan: Bethylidae (Hymenoptera). Touka Shobo, Fukuoka, 319p.

Waichert, C. \& C.O. Azevedo. 2009. Phylogenetic analysis of Rhabdepyris (Hymenoptera: Bethylidae) and redefinition of generic limits based on morphological characters Zootaxa 2284: 1-29.

Submitted: 15.IX.2009; Accepted: 26.III.2010.

Editorial responsibility: Gabriel L.F. Mejdalani 